ЕНЕРГЕТИКА

ТЕПЛОТЕХНІКА

ЕЛЕКТРОТЕХНІКА

ENERGETICS

HEAT ENGINEERING

ELECTRICAL ENGINEERING

UDC 621.039.56

T.O. Tsiselskaya, $\mathrm{PhD}$,

A.V. Kovtun, Master,

Odessa National Polytechnic University

\title{
AN AUTOMATED BORON MANAGEMENT SYSTEM FOR WWER-1000 NUCLEAR REACTORS
}

Introduction. The main function of the nuclear power plants (NPPs) operated in Ukraine is production of electricity. From a safety and reliability point of view, operation of any NPP at the nominal power level is the best mode. In practice, however, the power system imposes its own requirements and, therefore, the NPP needs to be able to change the plant output in order to provide load-following mode. Hence the modern automation systems at NPPs are subjected to the increased requirements. Primarily, this is related to subsystems of information collection, processing and analysis, as well as to control algorithms which should provide reliable and safe operating conditions [1].

The reactor facilities for operational control of WWER-1000 delivering $1000 \mathrm{MW}$ of electrical power are of great importance, as accidents at these facilities make the main contribution to radioactive contamination of the environment.

The use of boron regulation for controlling the power of WWER-1000 allows us to extend the ultimate output period ensuring the economic efficiency of the power unit, as well as to maintain the reactor facility in the relevant safety limits which guarantee the impossibility of an emergency occurrence. However, implementation of the boron regulation (BR) at a real nuclear power plant leads to emergence of xenon oscillations influencing the linear heat rate axial distribution, growth of the transient response time, increase of the energy emission unevenness in the reactor core (RC), and rise of the volume of liquid radioactive waste and wasteful consumption of boric acid (BA).

All in all, development of an automated boron management system providing an optimum process control is highly required for the nuclear power industry of Ukraine.

Analysis of recent research and publications. Sources analysis shows that the boron regulation methods available at Ukrainian NPPs are flawed due to the operational staff information support lack [2]. Also, the mentioned disadvantages list includes lack of operative information about concentration of

DOI 10.15276/opu.1.45.2015.09

(C) T.O. Tsiselskaya, A.V. Kovtun, 2015

ЕНЕРГЕТИКА. ТЕПЛОТЕХНІКА. ЕЛЕКТРОТЕХНІКА 
boric acid in the first loop, effective process quality criteria, methodology of the current situation assessment. The operator, carrying out the boron control, has no clear guidelines as to the process schedule, and is not able to assess and forecast the proposed actions' issues.

Both Ukrainian and foreign author's researches over the last 5 years do clearly reveal a tendency to develop main directions of power control optimization and power distribution system [3] by increasing the role of boron regulation while normal modes.

Important to note is that the accidents at nuclear power plants may lead to severe economical and ecological consequences. Therefore, when development and implementation of algorithms for BR process control it is advisable to forecast changes in the power unit basic parameters using simulation modeling.

The Aim of the Research. The effected research has been aimed onto improving the efficiency and reliability of decisions, taken by operational staff at WWER-1000 reactor facilities control, through the creation of boron regulation automated control system with the development and adaptation of optimal process control algorithms using mathematical models. These results allow indirect measurement of boric acid concentration, and adequate simulation models designing to predict the power unit main performance parameters.

Main Body. The effectiveness of boric acid $\rho_{b}\left(C_{b}\right)$ at concentration $C_{b}$ represents the value of reactivity, that the reactor loses while increasing the boric acid concentration in the coolant from 0 to $C_{b}$ :

$$
\rho_{b}\left(C_{b}\right)=\int_{0}^{C_{b}} \alpha_{b} d C_{b},
$$

where $\alpha_{b}=f\left(C_{b}\right)=\frac{\partial \rho_{b}}{\partial C_{b}}-$ coefficient of boric acid reactivity.

The value $\alpha_{b}$ has been determined for 284,72 effective days from the neutron characteristics catalog. $\alpha_{b}=-1,58 \% / \mathrm{g} / \mathrm{kg}=-0,01581 / \mathrm{g} / \mathrm{kg}$.

The boric acid concentration in the coolant is reduced due to injecting pure condensate into the first loop. Fig. 1 shows that the variation of boric acid and distilled water concentration follows the exponential law. For simulation, these dependencies have been identified and described with the following differential equations:

- at boric acid injection:

— at distilled water injection:

$$
T_{1} \frac{d C_{b}}{d \tau}+\Delta C_{b}=k_{1} \Delta G_{b}
$$

$$
T_{2} \frac{d C_{b}}{d \tau}+\Delta C_{b}=k_{2} \Delta G_{\mathrm{H}_{2} \mathrm{O}}
$$

where $C_{b}$ - concentration of boric acid, $\mathrm{g} / \mathrm{kg}$;

$$
\begin{aligned}
& k_{1}, k_{2}-\text { transmission gains, } \mathrm{g} / \mathrm{kg} / \mathrm{t} / \mathrm{h} ; \\
& T_{1}, T_{2} \text { - time constants, } s ; \\
& \Delta G_{b}-\text { flow rate variation of boric acid, } \mathrm{t} / \mathrm{h} ; \\
& \Delta G_{\mathrm{H}_{2} \mathrm{O}}-\text { flow rate variation of distilled water, } \mathrm{t} / \mathrm{h} .
\end{aligned}
$$

For the calculation we assumed that the nominal flow rate of boric acid is equal to $\Delta G_{b}=40 \mathrm{t} / \mathrm{h}$, the nominal flow rate of distilled water is equal to $\Delta G_{\mathrm{H}_{2} \mathrm{O}}=40 \mathrm{t} / \mathrm{h}$. Gains and time constants for such flows of boric acid and distilled water are therefore: $k_{1}=40 \mathrm{~g} / \mathrm{kg} / \mathrm{t} / \mathrm{h}, k_{2}=16 \mathrm{~g} / \mathrm{kg} / \mathrm{t} / \mathrm{h}$, $T_{1}=22318 \mathrm{~s}, T_{2}=47714,7 \mathrm{~s}$. 

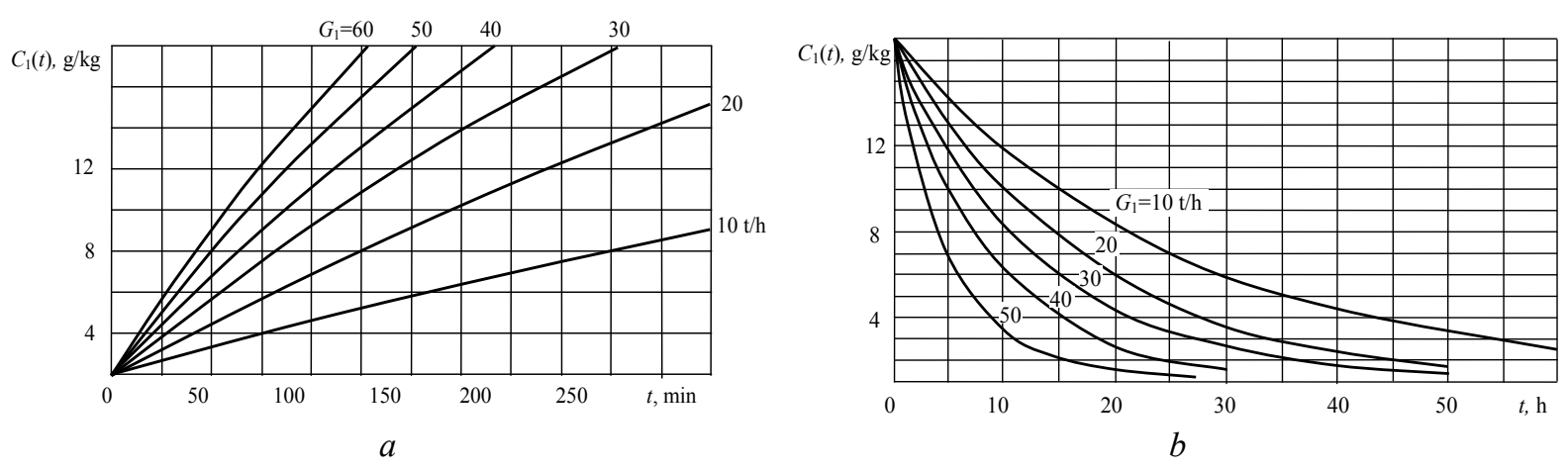

Fig. 1. Variation of boron concentration in the coolant when concentrated boric acid (a) and distilled water (b) adding

The boric acid input/output gain coefficients differ by 2,5 times, and input/output time constants are 2 times-differing. Consequently, we can conclude that the boric acid removal from the coolant through distilled water injection takes longer time.

Steady state conditions of RC

a) The reactor thermal power is maintained by automatic power regulator (APR) within accuracy range of $\pm 2 \%$ of nominal $N_{\text {nom }}$;

b) The control rods (CR) group is maintained within the motion adjustment range $(70 \ldots 90 \%$ from the reactor core bottom);

c) $K_{v}$ coefficients do not exceed values given in [2]: $K_{v}(i, j) \leq K_{v}^{\text {prev }}(i, j)$, where $i$ - number of point where measurements by the height of reactor core $(i=1,2,3, \ldots, 7)$ take place; $j$ - fuel assembly of reactor core $(j=1,2,3, \ldots ., 163)$

d) the axial offset value is found within the range : $-0,02 \leq A O \leq 0,15$

The assessment of boron regulation quality is implemented in terms of controlling the entire reactor facility and maintaining the RC steady state condition (listed in table). Characteristic feature of the steady state deterioration consists in reactivity change that, according to the safety technological regulation requirements, represents a signal for boron regulation starting. Therefore, proposed is to use the reactivity variation as a criterion for optimal control of boron regulation.

Current reactivity variation during normal operation at nominal power represents the following algebraic sum:

$$
\Delta \rho=\Delta \rho_{N}+\Delta \rho_{T^{\circ}}+\Delta \rho_{C R}+\Delta \rho_{b},
$$

where $\Delta \rho_{N}$ - reactivity contribution due to the power level change from $N_{1}$ to $N_{2}, \%$;

$\Delta \rho_{T^{\circ}}$ - reactivity contribution due to the change in reactor coolant average temperature from $T_{1}{ }^{\circ} \mathrm{C}$ to $T_{2}{ }^{\circ} \mathrm{C}, \%$;

$\Delta \rho_{C R}$ - reactivity contribution, defined by changes in the $C R$ group position from $H_{1}$ to $H_{2}, \%$;

$\Delta \rho_{b}$ - reactivity contribution depending on changes in the $B A$ concentration in loop from $C_{1}^{(1)}$ to $C_{1}^{(2)}, \%$.

The components (2) are known for any point of time and can achieve both positive and negative values depending on the initial and final power level, average coolant temperature, position of control rods and boron concentration in coolant. Also, total reactivity variation $\Delta \rho$ can acquire both positive and negative values. One of the operational staff main tasks relates to maintaining reactor's critical state, when $\Delta \rho=0$. At alternation of conditions, listed above (refer to table), there occur changes in 
the reactivity; generally such deterioration is determined by the sum of the first three members at equation (2):

$$
R=\Delta \rho_{N}+\Delta \rho_{T^{\circ}}+\Delta \rho_{C R},
$$

and $R \neq 0$.

The reactor is returned to the critical state by adding the opposite reactivity variation at the expense of increasing or decreasing BA concentration in the coolant $1^{\text {st }}$ loop. Considering the above mentioned, the target function can be represented as follows:

$$
I=\int_{0}^{t}\left(R-\Delta \rho_{b}\right)^{2} d t \rightarrow \min ,
$$

The minimized functional of boron regulation has been obtained in the following form:

$$
\begin{gathered}
I=\alpha_{b}^{2} \frac{\left[C_{1}(0)-C_{2}\right]^{2}}{2 A} \exp (2 A t)+2 \alpha_{b} \frac{C_{1}(0)-C_{2}}{A}\left[\alpha_{b}\left(C_{2}-C_{1}(0)\right)-R\right] \exp (A t)+ \\
+\left\{\left(R-\alpha_{b} C_{2}\right)^{2}-\alpha_{b} C_{1}(0)\left[2 R-\alpha_{b} C_{1}(0) C_{2}+2\right]\right\} t-\alpha_{b} \frac{C_{1}(0)-C_{2}}{A}\left\{\frac{3 \alpha_{b}\left[C_{1}(0)-C_{2}\right]}{2}-2 R\right\} \rightarrow \text { min, }
\end{gathered},
$$

where $\alpha_{b}^{2}-$ differential efficiency of boric acid, $\% / \mathrm{g} / \mathrm{kg}$;

$C_{1}(0)$ - concentration of boric acid in the $1^{\text {st }}$ loop at the initial time, $\mathrm{g} / \mathrm{kg}$;

$C_{2}$ - concentration of boric acid in the feedwater, $\mathrm{g} / \mathrm{kg}$;

$A=G_{1} / V_{1} ; G_{1}$ - flow rate of feedwater, $\mathrm{m}^{3} / \mathrm{h}$;

$V_{1}$ - coolant amount in the $1^{\text {st }}$ loop, $\mathrm{m}^{3}$;

$R$ - reactivity variation caused by the deterioration of RC steady state, $\%$.

The boundary conditions:

$$
\begin{gathered}
0 \leq C_{2} \leq 16 \mathrm{~g} / \mathrm{kg}, \\
t>0 .
\end{gathered}
$$

The final value of boric acid concentration $C_{1}(t)$ can be found using a hydrodynamic model of the $1^{\text {st }}$ loop and inflow-outflow system.

As far as $I=f\left[t\left(C_{2}\right)\right]$, then the necessary condition for an extremum of functional $I$ is equal to $\frac{d I(t)}{d t}=0$ :

$$
\begin{gathered}
y^{2}+2\left[\frac{C_{2}-C_{1}(0)}{C_{1}(0)-C_{2}}-\frac{R}{\alpha_{b}\left(C_{1}(0)-C_{2}\right)}\right] y+\frac{R^{2}}{\alpha_{b}^{2}\left(C_{1}(0)-C_{2}\right)^{2}}- \\
-\frac{2 R\left(C_{1}(0)+C_{2}\right)}{\alpha_{b}\left(C_{1}(0)-C_{2}\right)^{2}}+\frac{\left(C_{2}-C_{1}(0)\right)^{2}}{\left(C_{1}(0)-C_{2}\right)^{2}}=0,
\end{gathered}
$$

where $y=\exp (A t)$.

The expression used to find the optimal time of boron regulation has been obtained through equation (8) roots analysis:

$$
t=-\frac{V_{1}}{G_{1}} \ln \left(\frac{R-\alpha_{B A}\left(C_{2}-C_{1}(0)\right)-4 \sqrt{R \alpha_{b} C_{1}(0)}}{\alpha_{b}\left(C_{1}(0)-C_{2}\right)}\right) .
$$

The optimal boron regulation task has been reduced to finding such boric acid concentration $C_{2}$ in feedwater, when the function (9) would reach a minimum positive value $(t>0)$ providing a minimum of the functional (5) with the use of necessary and sufficient conditions for the single variable function's extrema. 
Taking into consideration the afore exposed, the synthesis algorithm for optimal boron real-time control while reactor facility operation, based on changes in reactivity, should include the following basic operations:

1. The assessment of nuclear reactor core current state at discrete points in time corresponding to the beginning of the next cycle of control formation is determined by calculating reactivity variation using formula (2).

2. The reactor going out of critical state necessary is to find the minimum of function (5) within constraints (6) and (7). The values of transient response time $t$ and $B A$ concentration $C_{2}$ in feedwater represent the calculation results.

3. It is suggested to calculate final concentration value $C_{1}(t)$ in the first loop coolant by RungeKutta method in the interval $[0, t]$ using the obtained values $t$ and $C_{2}$. If $C_{1}(t)<C_{1}(0)$, then it is necessary to add the distilled water, when otherwise, required is to feed with concentrated boric acid.

4. The calculation of concentrated $B A$ or distilled water volume required to inject for returning the reactor's critical state, follows the formula:

$$
V_{\text {feed }}=G_{1} \cdot t,
$$

where $V_{\text {feed }}$ - feeding volume, $\mathrm{m}^{3}$;

$G_{1}$ - feeding flow rate into the coolant of $1^{\text {st }}$ loop, $\mathrm{m}^{3} / \mathrm{h}$;

$t$ - time during which it is necessary to carry out feeding, $\mathrm{h}$.

5. Forming the instructions for operator, providing him with the found values: feeding volume $V_{\text {feed }}$ and feeding time $t$, boric acid concentration $C_{2}$ in feedwater, final value of boric acid concentration $C_{1}(t)$ in coolant of $1^{\text {st }}$ loop.

Hence we proposed a project of automatic control system (ACS) with boron regulation based on algorithm mentioned above. Having analyzed the existing software and instrumentation tools for building distributed automation systems, and taking into account the features of control systems for WWER-1000reactor facilities, we selected necessary hardware and software tools of Holit Data Systems Company. As the main option, we propose to use the tetraCON complex on the RS-485 and Ethernet network basis.

The tetraCON includes a family of programmable PC-compatible controllers tinyCON, series of remote terminal units modules (RTU) tCON, which provide a standard interface with sensors and actuators, as well as interface converters RS232/485.

The structure of BR automatic control system on the tetraCON modules base is shown at Fig. 2 .

The proposed control system functioning is described below. The $R C$ current state data is forwarded to $B R$ operator workstation via Ethernet. When reactor goes out off critical state required procedure includes calculating such parameters as: time $t$ and feeding volume $V_{\text {feed }}, B A$ concentration $C_{2}$ in feedwater and magnitude of concentration $C_{1}(t)$. Subsequently, departing from results obtained, the system generates special recommendations to operator with found values data.

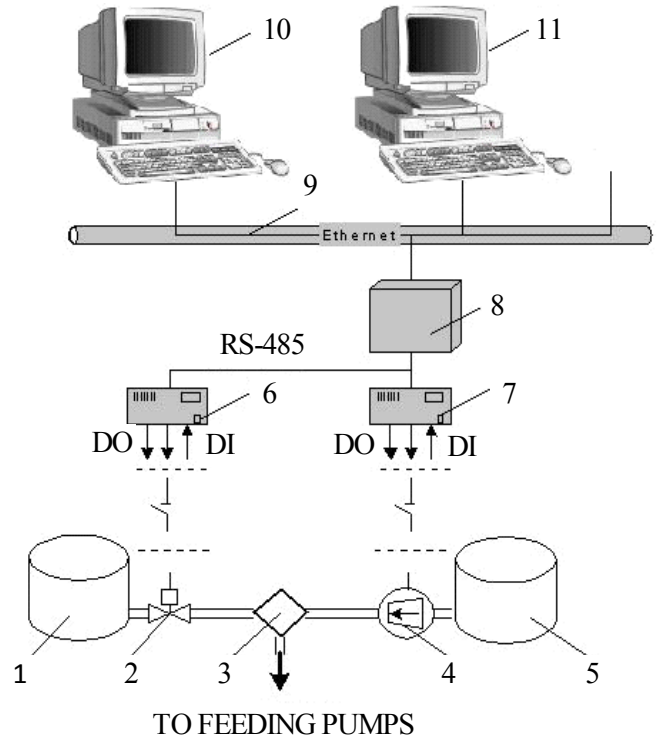

Fig. 2. Structure of BR automatic control system (ACS): 1 - tank with distilled water; 2 - electrified gate valve; 3 - suction collector of feeding pumps; 4-centrifugal pump; 5-tank with concentrated BA; 6, 7-RTU; 8-PC-compatible controller; 9 -local area network Ethernet;

$10-$ BR operator workstation; 11 - workstation of operational staff 
Results. Any deviation of reactor core state's one or several parameters from the values listed in table is called an event.

On the basis of normal operation real data the following events have been simulated:

1. Deviation from nominal power level by more than $2 \%$.

2. $C R$ group reaching the edge or out of the adjustment range limits.

3. Exceeding the limit tolerance values $K_{v}$ in $R C$ bottom part.

4. Exceeding the limit tolerance values $K_{v}$ in $R C$ upper part.

5. $A O$ values deviation from the recommended range.

Changes in core parameters have been investigated for each of mentioned events. Experimental calculations were carried out using $B R$ control system being held in two stages. In the first stage the forecast was taking into account the recommendations developed by $A C S$, in the second stage the prognosis did not include any recommendations. The results obtained during experimental series have been compared with the real data (Fig. 3). Here the index "1" is marking results obtained in the first stage, and the index "2" refers to the second stage, "INIT" — archival data.
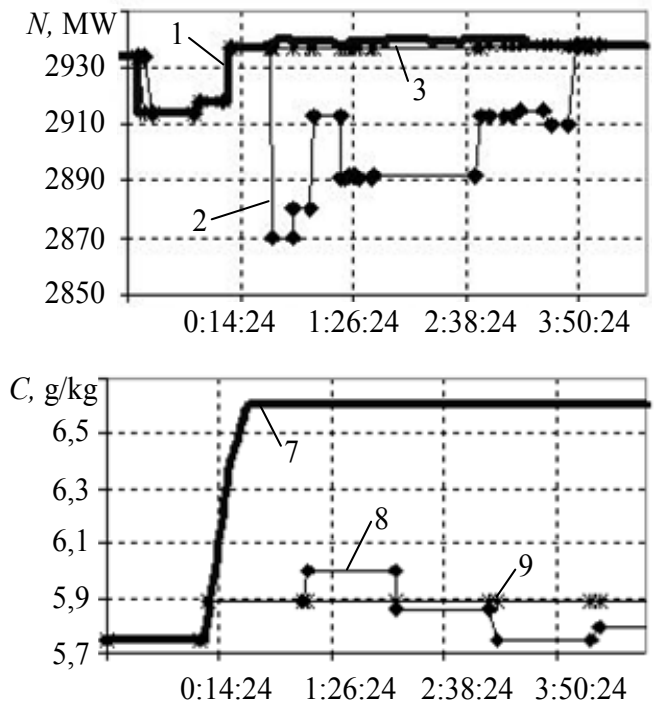
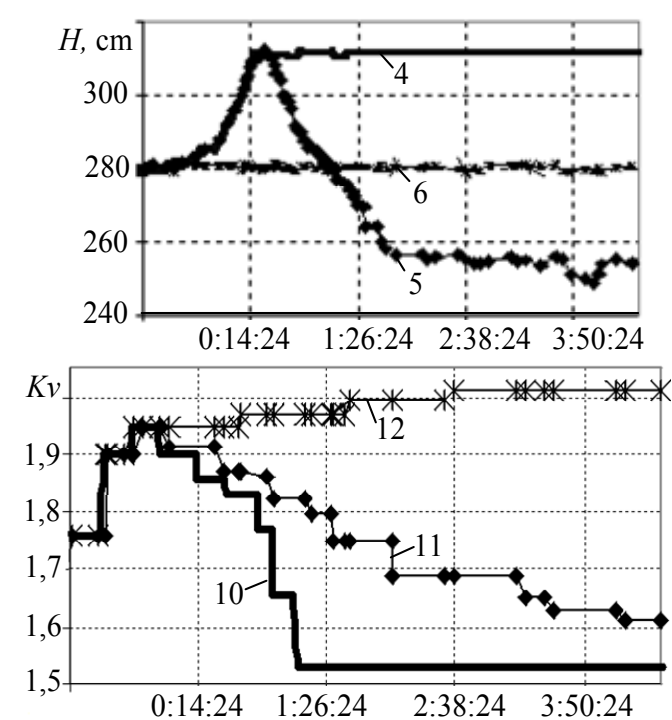

Fig. 3. Example of forecasting the reactor facility parameters in the mode of limit values exceeded warning $K_{v}$ : $1-N 1 ; 2-N I N I T ; 3-N 2 ; 4-H 1 ; 5-H I N I T ; 6-H 2 ; 7-C 1 ; 8-C I N I T ; 9-C 2 ; 10-K V 1 ; 11-$ KVINIT; $12-K V 2$

Conclusions. The investigated process of boron regulation within reactor facility has a great importance for the nuclear power plants operation.

The proposed criterion of optimal boron regulation ensures minimal reactivity variation in critical state reactor control and maintenance. As we found, the problems, associated with boron regulation, may be solved using automated boron control system which enables to generate special recommendations for operational staff including data on the duration of transient response time, feeding volume, values of final boric acid concentration in $1^{\text {st }}$ loop coolant, and the mode of boric acid or distilled water input.

\section{Лiтература}

1. Исаев, А.Н. МАГАТЭ и вопросы обеспечения безопасности / А.Н. Исаев // Атомная техника за рубежом. - 2001. - № 8 . - С. $3-7$.

2. Instrumentation and control systems important to safety in nuclear power plants: safety guide. — Vienna: International Atomic Energy Agency, 2002. — 91 p. 
3. Maksimov, M.V. A model of a power unit with VVER-1000 as an object of power control / M.V. Maksimov, K.V. Beglov, T.A. Tsiselskaya // Пр. Одес. політехн. ун-ту. —2012. — No. 1(38). — C. $99-106$.

\section{References}

1. Isaev, A.N. (2001). IAEA and security issues. Atomnaya Tekhnika za Rubezhom, 8, 3-7.

2. Instrumentation and control systems important to safety in nuclear power plants: safety guide. - Vienna: International Atomic Energy Agency, 2002. — 91 p.

3. Maksimov, M.V., Beglov, K.V. and Tsiselskaya, T.A. (2012). A model of a power unit with VVER1000 as an object of power control. Odes'kyi Politechnichnyi Universytet. Pratsi, 1, 99-106.

\section{АНОТАЦІЯ / АННОТАЦИЯ / ABSTRACТ}

Т.О. Цисельська, А.В. Ковтун. Система автоматизованого керування процесом борного регулювання в ядерних реакторах типу ВВЕР-1000. Стаття присвячена актуальному завданню створення системи автоматизованого керування процесом борного регулювання в водо-водяному енергетичному реакторі ВВЕР-1000. Застосування борного регулювання для керування реакторами типу ВВЕР-1000 дозволяє збільшити час роботи на максимальній потужності, забезпечуючи економічну ефективність експлуатації енергоблоку, а також підтримувати реакторну установку в потрібних безпечних межах, які роблять неможливим виникнення і розвиток аварійних ситуацій. Результати вирішення цього завдання, пов'язані з моделюванням, оптимізацією і прогнозом процесу, були використані для подальшої розробки комп'ютерно-інтегрованої системи управління, яка дозволяє підвищити ефективність рішень, що приймаються оперативним персоналом в процесі керування реакторною установкою.

Ключові слова: ВВЕР-1000, система керування, математична модель, оптимізація процесу, прогноз параметрів.

T.A. Цисельская, А.В. Ковтун. Система автоматизированного управления процессом борного регулирования в ядерных реакторах типа ВВЭР-1000. Статья посвящена актуальной задаче создания системы автоматизированного управления процессом борного регулирования в водо-водяном энергетическом реакторе ВВЭР-1000. Применение борного регулирования для управления реакторами типа ВВЭР-1000 позволяет увеличить время работы на максимальной мощности, обеспечивая экономическую эффективность эксплуатации энергоблока, а также поддерживать реакторную установку в нужных безопасных пределах, делающих невозможным возникновение и развитие аварийных ситуаций. Результаты решения этой задачи, связанные с моделированием, оптимизацией и прогнозом процесса, были использованы для дальнейшей разработки компьютерно-интегрированной системы управления, позволяющей увеличить эффективность решений, принимаемых оперативным персоналом в процессе управления реакторной установкой.

Ключевые слова: ВВЭР-1000, система управления, математическая модель, оптимизация процесса, прогноз параметров.

T.O. Tsiselskaya, A.V. Kovtun. An automated boron management system for WWER-1000 nuclear reactors. The article is devoted to the problem of creating a system of automated control with boron regulation for reactor WWER-1000 series. Using the boron regulation to control WWER-1000 allows to extend its maximum output operation period, ensuring the economic efficiency of the power unit, as well as to maintain the reactor facility within relevant safety limits that prevents from emergencies occurrence and development. The results of this problem solution, related to the process simulation, optimization and prediction, were used at further development of computer-integrated control system increasing the efficiency of decisions, taken by operational staff at reactor control.

Keywords: WWER-1000, boron regulation, control system, mathematical model, process optimization, prediction of parameters. 